\title{
Sorghum bicolor (L.) Moench. - Plant for the future in Moldavia agriculture (Romania) and for the human nutrition
}

\author{
Simona - Florina Isticioaia ${ }^{1}{ }^{*}$, Alexandra Leonte ${ }^{1}$, Lorena - Diana Popa ${ }^{1}$, Elena Trotuș ${ }^{1}$, \\ Livia Apostol ${ }^{2}$, Iulian Voicea ${ }^{3}$ and Gheorghe Matei ${ }^{4}$ \\ ${ }^{1}$ Agricultural Research and Development Station Secuieni, 371 Principală Street, Neamț, Romania \\ ${ }^{2}$ National Institute of Research and Development for Food Bioresources, 5 Ancuta Baneasa Street, \\ 2nd District, Romania \\ ${ }^{3}$ National Institute of Research - Development for Machines and Installations Designed to \\ Agriculture and Food Industry, 6 B-dul Ion Ionescu de la Brad, 1st District, Romania \\ ${ }^{4}$ University of Craiova, 13 A. I. Cuza Street, nr. 13, Craiova, România (coordinator)
}

\begin{abstract}
In the climatic conditions of the Center of Moldavia (Romania), there are eight sorghum hybrids cultivated for grains (Arsky, Foehn, Albanus, Shamal, Kalatur și Armorik, Elan and Alimentar) in order to establish their adaptability to the conditions of the area, by taking into account the current problems of agriculture caused by climate change and the need to find a solutions to fight hunger and improve human health. This study focused on two directions, namely: identifying genotypes that achieve the highest productions and establishing food value and the benefits of sorghum grains on human health by analysing the physico chemical composition of the grains, by determining the mineral content of the grain and by determining the composition in amino acids. The grain production had ranged from $8623 \mathrm{~kg} / \mathrm{ha}$ to $11181 \mathrm{~kg} / \mathrm{ha}$. This production had characterized by a protein content between $8.84 \%$ and $12.80 \%$, in lipid content between $3.39 \%$ and $4.15 \%$, in raw fibre content between $2.15 \%$ and $3.95 \%$ and the starch content was between $66.70 \%$ and 74.66 $\%$. The analysed mineral content of the sorghum samples has the following values $(\mathrm{mg} / 100 \mathrm{~g}$ a.s.): phosphorus - 280 - 330; potassium - $520-610$; calcium - 2.4 - 3.9; magnesium - 260 - 290; iron - 11.6 - 18.9; zinc - 1.94 2.42; copper $-0.23-0.36$; manganese - $1.60-1.97$. Analysing the amino acid composition of sorghum samples it can be said that the samples contain all the essential amino acids, in concentrations that, some of them, exceed the recommended daily dose (FAO/WHO/UNU): leucine, isoleucine, histidine, valine. Also the analysed sorghum seeds add an important content of methionine, threonine and phenylalanine.
\end{abstract}

Key words: climatic change, genotypes, mineral composition, grain sorghum, yield

\footnotetext{
*Corresponding author : simonapochi@yahoo.com; matei.gheorghe@gmail.com
} 


\section{Introduction}

Sorghum (Sorghum bicolor (L.) Moench.) has long been considered a "miracle culture", solving many problems that the planet has, which is increasingly populated and hungry due to global warming and in continuous search for solutions for obtaining bioenergy.

The genus Sorghum belongs to the family Poaceae (Gramineae), the subfamily Panicoideae, the tribe Andropogoneae, the subtribe Sorghinae [1]. The genus Sorghum contains a very diverse group of plants, which made it very difficult to classify sorghum varieties in domesticated and wild [2]. It originates from North - East Africa and was first cultivated 4000 years ago [3].

Sorghum is a cereal of high importance, being in fifth place in the world after the production of grains (57.6 million tonnes) after corn, wheat, rice and barley [4]. It has a great development due to its use in human nutrition, especially in the semi-arid areas of the world, where pedoclimatic conditions offer limited conditions for agriculture. Such situations are mainly in Africa, Asia and Latin America, areas that are frequently affected by drought [5], here sorghum is one of the most important crops representing the main source of energy and nutrition for people [6]. In western countries, such as the United States, Mexico and Australia, sorghum is mainly grown for animal feed, but there is a growing interest in its use for biofuel production, as well as for use in human nutrition, having given its chemical composition, which is beneficial for the development of healthy and functional foods [7].

The agronomic importance of sorghum culture is given by the resistance to drought and to the high temperatures, which gives the adaptability of this plant in the tropical and subtropical areas, in the context of the climatic changes of desertification of some areas of the globe. In addition to its high tolerance to drought and high temperatures, sorghum also has the advantage of its cultivation at high altitudes and in saline - alkaline and inert soils. These advantages are due to the fact that sorghum has a well-developed root system and the leaves are protected by wax [3]. The species can grow under the conditions of precipitation amounts below $100 \mathrm{~mm}$ precipitation / growth cycle, the critical drought period is about 20 days shorter than in maize ( 27 days in sorghum and 46 days in maize), and pollen can withstand high temperatures of $45-50{ }^{\circ} \mathrm{C}$, while corn pollen resists up to $35-40{ }^{\circ} \mathrm{C}$. Another advantage of sorghum culture is its resistance to disease and pests. Also, sorghum has low requirements for nutrient requirements, having a well-developed root system, it allows it to extract all the nutrients it needs from the soil.

In addition to its agronomic benefits, sorghum is very nutritionally valuable. Sorghum beans can be an excellent source of starch, protein, sugar, fibre, being much cheaper compared to other crops. Grains are gluten-free, rich in starch and in nutrients and, most importantly, contain a wide range of bioactive phenolic compounds [8]. The unique phenolic profile gives sorghum a number of benefits to human health, such as reducing oxidative stress and preventing cancer [9].

Due to its superior agronomic properties and its potential to be used in human health, sorghum has attracted considerable attention in recent decades from researchers and the food and drug industries. With the ever-increasing change in consumer demand for healthy, plant-based foods, sorghum has enormous potential for exploitation and development in healthy and functional foods and food additives $[10,11]$. The nutritional composition of sorghum varies depending on the cultivated hybrid. In general, carbohydrates (starch and non-starch polysaccharides), proteins and lipids are the main compounds of the grain [12]. On average, $100 \mathrm{~g}$ of sorghum contains about $72.1 \mathrm{~g}$ of carbohydrates, $12.4 \mathrm{~g}$ of water, 10.6 $\mathrm{g}$ of protein, $6.7 \mathrm{~g}$ of fibre and $3.5 \mathrm{~g}$ of fat and provides approximately $1.377 \mathrm{~kJ}$ of energy [13]. Starch is the dominant carbohydrate and varies depending on the hybrid, from $32.1 \mathrm{~g}$ to $72.5 \mathrm{~g}$ to $100 \mathrm{~g}$ of grains [14]. Sorghum is a rich source of fibres, because non-starch 
carbohydrate in sorghum is composed of insoluble fibres (75\% to $90 \%)$ and soluble fibres $(10 \%-25 \%)$, which are found in the walls of the pericarp and endosperm cells - $15 \mathrm{~g}$ to $100 \mathrm{~g}$ of berries [15].

Sorghum protein can be broadly divided into prolaminic proteins (kafirins) and nonprolaminic proteins (globulins, glutelin and albumin). Kafirins are the main proteins, accounting for $70 \%$ of the total protein, while albumin, glutelin and globulin represent the rest [16]. Sorghum beans are rich in glutamic acid, proline and leucine [17]. Sorghum proteins have low digestibility. Kafirins have high degree of polymerization and extensive disulphide bridges that are resistant to enzymatic digestion in the digestive tract and strong interaction with tannins and starch also impedes protein digestion [18]. These characteristics make sorghum a promising source of food for people suffering from obesity and diabetes [19].

Lipids from sorghum are mainly unsaturated fatty acids, being represented in particular by oleic, linoleic, palmitic, linolenic and stearic acids [13].

Sorghum is also an important source of vitamins and minerals. Vitamin B complex (pyridoxine, riboflavin and thiamine) and some fat-soluble vitamins (A, D, E and $\mathrm{K}$ ) are the main vitamins in sorghum, and potassium, phosphorus, magnesium and zinc are the main minerals $[13,15]$.

Considering the current problems of agriculture caused by climate change and the need to find a solutions to fight hunger and improve human health, in the climatic conditions of the Center of Moldavia (Romania), we have conducted studies on eight sorghum hybrids cultivated for grains (Arsky, Foehn, Albanus, Shamal, Kalatur şi Armorik, Elan and Alimentar). This study focused on two directions, namely: identifying genotypes that achieve the highest productions and establishing food value and the benefits of sorghum grains on human health by analysing the physico - chemical composition of the grains.

\section{Methodology}

In the pedoclimatic conditions from the Agricultural Research and Development Station Secuieni (Center of Moldova), researches were carried out regarding the adaptability of some grain sorghum hybrids to the conditions of the area and their influence on its production and quality. The experiments were performed on a typical Cambodian chernozem soil type, characterized as being normally supplied with mobile phosphorus $\left(\mathrm{P}_{2} \mathrm{O}_{5}-39 \mathrm{ppm}\right)$, and mobile potassium $\left(\mathrm{K}_{2} \mathrm{O}-161 \mathrm{ppm}\right)$, moderately supplied with nitrogen (nitrogen index of soil: 2.1), weak acid (pH: 6.29) and weakly fertile (humus content $2.3 \%$ ) and in extremely adverse climatic conditions to agricultural crops. Both years of experimentation (2018 and 2019) presented during the vegetation period climatic conditions characterized as very dry and warm.

The experience was monofactorial, the factor being the sorghum hybrid for grains, and its placement in the field was carried out following the randomized blocks method, in three repetitions. As far as the experimental data are concerned, they were processed by statistical methods specific to the monofactorial experiences, and their interpretation was made by the variance analysis. The biological material came from the companies Euralis Seeds (Arsky, Foehn, Albanus, Shamal, Kalatur and Armorik hybrids) and from the Porumbeni Institute of Phytotechnics (Elan and Alimentar hybrids). The technology performed in the experimental field was the one specific for the pedoclimatic conditions in the Center of Moldova. The sowing distribution was $300000 \mathrm{Gg} / \mathrm{ha}$ and the precursor plant was the sunflower.

The sorghum berries have been analysed in 2018 - 2019 period from a physical, chemical and nutritional point of view, using modern methods of analysis, apparatus and equipment for analysis, measurement and processing specific to raw materials and products 
(https://erris.gov.ro/Food-Chemistry -Laboratory; https://erris.gov.ro/Microbiology-ELISALaboratory; https://erris.gov.ro/Food-Packaging-Laboratory), which is endowed with the National Institute for Research and Development for Food Bioresources Bucharest.

\section{Results and discussions}

The production results obtained under the conditions of A.R.D.S. Secuieni showed that sorghum, although it suffered during the vegetation period from unfavourable climatic conditions, showed adaptability and the obtained productions were substantial.

The average production (2018 - 2019) obtained at the sorghum showed great variations depending on the hybrid and was between $7841 \mathrm{~kg} / \mathrm{ha}$, as recorded in the variant sown with the Elan hybrid, and $9718 \mathrm{~kg} / \mathrm{ha}$, production recorded in the variant sown with Shamal hybrid. For comparison, we used the average of the experience as a witness, and the differences obtained in relation to this were statistically ensured in three of the variants, namely: in the variant sown with the Elan hybrid the difference was negative and interpreted as significant, and in the variants sown with the Foehn hybrids and Shamal, the differences were positive and interpreted as significant and distinctly significant (fig. 1).

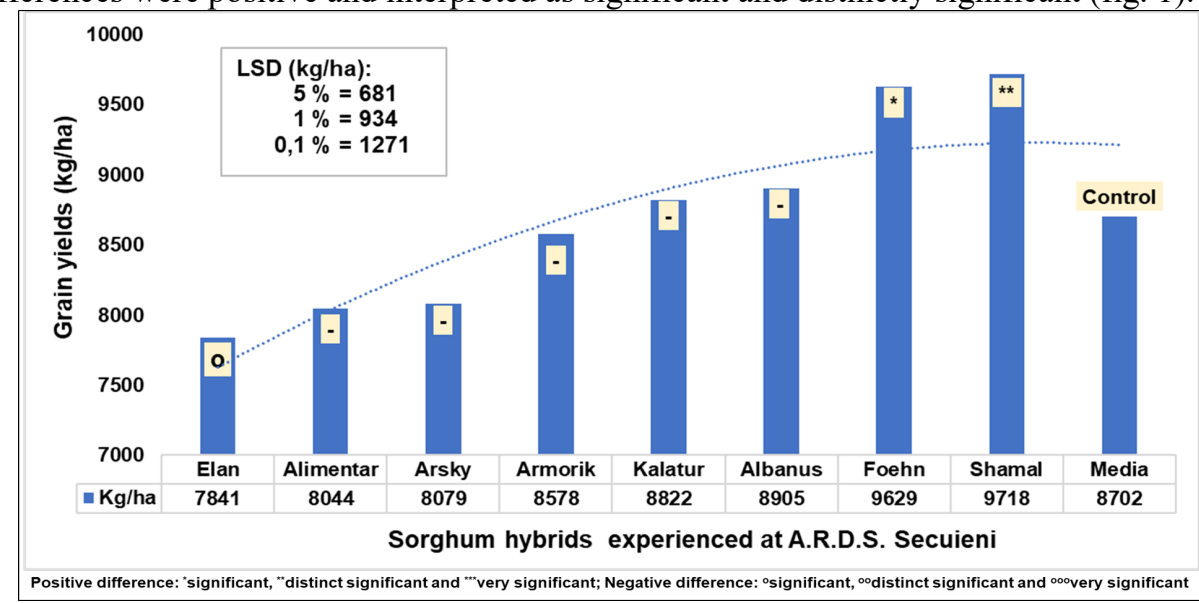

LSD means Least significant difference (For positiv values - Differences larger than LSD 5\% level are significant and are indicated with ${ }^{*}$, differences larger than LSD $1 \%$ level are distinctly significant and are indicated with ${ }^{* *}$ and differences larger than LSD $0,1 \%$ level are verry significant and are indicated with ${ }^{* * *}$ and for negativ values the ${ }^{*, * * * * *}$ is replaced with ${ }^{\mathrm{O}, \mathrm{OO}, \mathrm{OOO}}$.

Fig. 1. Grain yields obtained from sorghum under pedoclimatic conditions of the A.R.D.S. Secuieni, average $2018-2019$

In order to identify hybrids with high dietary value, the samples collected from the experimental field were analyzed and the results obtained indicated large variations of the physical and chemical indices depending on the genotype.

The physical indices of the seed are generally influenced by the characteristics of the hybrid and by the climatic conditions of the grain formation and filling period. Under the conditions at Secuieni, they varied according to the hybrid experienced, the values of the mass of one thousand grains being between $27.8 \mathrm{~g}$ (Armorik hybrid) and $33.0 \mathrm{~g}$ (Alimentar hybrid), and those of the hectolitric mass between $73.1 \mathrm{~kg} / \mathrm{hl}$ and $76.6 \mathrm{~kg} / \mathrm{hl}$ (Armorik and Foehn hybrids) (fig. 2). 


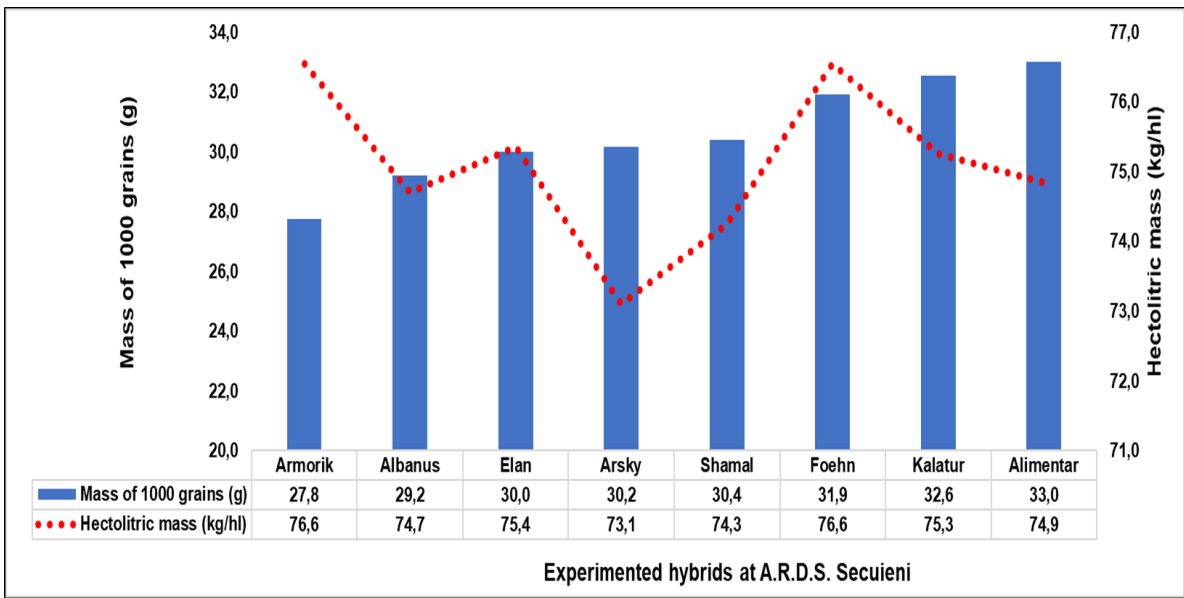

Fig. 2. The values of the physical indices of the sorghum seed obtained at A.R.D.S. Secuieni, average $2018-2019$

Sorghum is the cereal that contains the most nutrients and, according to the latest researches, it can reduce severe asthma attacks and fights migraine. The results obtained from the analysis of the physico-chemical composition of the sorghum samples collected from the experimental field showed that the studied hybrids had a high content in starch, between $66.70 \%$ (Foehn hybrid) and $74.66 \%$ (Armorik hybrid) and protein total, from $8.84 \%$ (Shamal hybrid) to $12.80 \%$ (Elan hybrid), which makes them advantageous for use in bakery (Table 1).

Considering that the percentage of raw fiber, between $2.15 \%$ (Arsky hybrid) and 3.95 $\%$ (Albanus hybrid), is double that of wheat flour, they take on importance in human health (Table 1).

Table 1. Physico - chemical composition of the experienced sorghum hybrids

\begin{tabular}{|l|c|c|c|c|c|}
\hline \multirow{2}{*}{ Hybrid } & \multicolumn{5}{|c|}{ Physical - chemical composition of sorghum grains (\% su) } \\
\cline { 2 - 6 } & Proteins & Lipids & Raw fibre & Starch & Ash \\
\hline Arsky & 11.11 & 3.44 & 2.15 & 70.42 & 1.67 \\
\hline Foehn & 9.64 & 3.90 & 2.69 & 66.70 & 1.60 \\
\hline Albanus & 10.56 & 3.39 & 3.95 & 68.02 & 1.66 \\
\hline Shamal & 8.84 & 3.94 & 2.30 & 67.37 & 1.49 \\
\hline Kalatur & 10.57 & 3.82 & 2.64 & 66.94 & 1.61 \\
\hline Armorik & 10.30 & 4.15 & 3.02 & 74.66 & 1.71 \\
\hline Elan & 12.80 & 3.74 & 2.37 & 67.20 & 1.89 \\
\hline Alimentar & 12.32 & 3.80 & 2.55 & 67.66 & 1.80 \\
\hline
\end{tabular}

The mineral content of the sorghum samples analysed (mg/100g a.s.) had phosphorus values between 280 - 330, potassium between 520 and 610, calcium between 2.0 and 3.9, magnesium between 260 and 290, iron between 11.6 and 18.9, zinc between 1.94 and 2.42, copper between 0.23 and 0.36 and manganese between 1.60 and 1.97 (Table 2).

Table 2. Mineral content determined in sorghum hybrids experimented

\begin{tabular}{|l|c|c|c|c|c|c|c|c|}
\hline \multirow{2}{*}{ Hybrid } & \multicolumn{8}{|c|}{ Minerals content (mg/100 g a.s.) } \\
\cline { 2 - 9 } & $\mathrm{P}$ & $\mathrm{K}$ & $\mathrm{Ca}$ & $\mathrm{Mg}$ & $\mathrm{Fe}$ & $\mathrm{Zn}$ & $\mathrm{Cu}$ & $\mathrm{Mn}$ \\
\hline Arsky & 280 & 610 & 2.6 & 270 & 14.3 & 2.02 & 0.32 & 1.60 \\
\hline Foehn & 330 & 530 & 3.9 & 280 & 18.9 & 2.42 & 0.28 & 1.93 \\
\hline Albanus & 320 & 520 & 2.7 & 290 & 16.3 & 2.20 & 0.33 & 1.97 \\
\hline
\end{tabular}




\begin{tabular}{|l|l|l|l|l|l|l|l|l|}
\hline Shamal & 280 & 600 & 3.8 & 260 & 13.6 & 1.94 & 0.23 & 1.70 \\
\hline Kalatur & 290 & 520 & 2.4 & 270 & 11.6 & 2.07 & 0.35 & 1.82 \\
\hline Armorik & 320 & 600 & 2.9 & 290 & 15.4 & 1.97 & 0.28 & 1.70 \\
\hline Elan & 320 & 540 & 2.4 & 280 & 14.0 & 2.18 & 0.29 & 1.96 \\
\hline Alimentar & 330 & 570 & 3.4 & 290 & 13.7 & 2.14 & 0.36 & 1.92 \\
\hline
\end{tabular}

Comparing the results obtained (Table 2) with the daily mineral reference dose (RDI) to ensure the proper functioning of human metabolic processes (Table 3), we observe that 100 $\mathrm{g}$ of sorghum flour can provide more than half of the daily iron dose, the Foehn hybrid as a whole and over half the daily dose of magnesium, and the potassium content is quite satisfactory. In view of these aspects, the term "iron source" and "magnesium source" may be emitted [20,21].

Table 3. Daily reference consumption (RDI) of macronutrients and micronutrients [22].

\begin{tabular}{|c|c|}
\hline Mineral (maximum for sex and age groups) & Acceptable daily intake (ADI) \\
\hline Calcium & $1000 \mathrm{mg}$ \\
\hline Iron & $18 \mathrm{mg}$ \\
\hline Magnesium & $400 \mathrm{mg}$ \\
\hline Zinc & $15 \mathrm{mg}$ \\
\hline Copper & $2000 \mu \mathrm{g}$ \\
\hline Sodium & $2400 \mathrm{mg}$ \\
\hline Potassium & $4700 \mathrm{mg}$ \\
\hline
\end{tabular}

The results of identifying essential amino acids in sorghum samples revealed that sorghum contains all the essential amino acids, some of which such as leucine, isoleucine, histidine and valine exceeding the recommended daily dose (FAO/ WHO/UNU). Also the sorghum seeds analyzed had an important content of methionine, threonine and phenylalanine (Table 4).

Table 4. Amino acid composition of sorghum samples collected from experimental field

\begin{tabular}{|l|c|c|c|c|c|c|c|c|}
\hline & \multicolumn{7}{|c|}{ Amino Acid Composition (\%) } \\
\hline \multicolumn{1}{|c|}{ Amino acid } & Arsky & Foehn & Albanus & Shamal & Kalatur & Armorik & Elan & Alimentar \\
\hline Aspartic acid & 0.60 & 0.55 & 0.56 & 0.48 & 0.59 & 0.57 & 0.60 & 0.50 \\
\hline Glutamic acid & 2.12 & 1.95 & 1.84 & 1.63 & 2.01 & 1.93 & 2.08 & 1.80 \\
\hline Seryn & 0.44 & 0.39 & 0.38 & 0.32 & 0.41 & 0.39 & 0.44 & 0.37 \\
\hline Glycin & 0.31 & 0.32 & 0.29 & 0.26 & 0.30 & 0.29 & 0.34 & 0.28 \\
\hline Histidine & 0.20 & 0.20 & 0.18 & 0.17 & 0.20 & 0.19 & 0.22 & 0.17 \\
\hline Arginine & 0.36 & 0.36 & 0.35 & 0.30 & 0.36 & 0.34 & 0.38 & 0.33 \\
\hline Threonine & 0.31 & 0.29 & 0.26 & 0.24 & 0.28 & 0.27 & 0.30 & 0.25 \\
\hline Alanine & 0.86 & 0.78 & 0.77 & 0.68 & 0.82 & 0.79 & 0.87 & 0.76 \\
\hline Proline & 0.89 & 0.82 & 0.76 & 0.66 & 0.82 & 0.77 & 0.89 & 0.76 \\
\hline Tyrosine & 0.32 & 0.30 & 0.27 & 0.19 & 0.24 & 0.25 & 0.30 & 0.27 \\
\hline Valine & 0.50 & 0.47 & 0.45 & 0.39 & 0.47 & 0.44 & 0.49 & 0.43 \\
\hline Methionine & 0.16 & 0.16 & 0.16 & 0.14 & 0.14 & 0.14 & 0.19 & 0.17 \\
\hline Cysteine & 0.11 & 0.10 & 0.11 & 0.12 & 0.12 & 0.14 & 0.13 & 0.12 \\
\hline Isoleucine & 0.37 & 0.34 & 0.34 & 0.29 & 0.36 & 0.34 & 0.39 & 0.33 \\
\hline Leucine & 1.30 & 1.16 & 1.16 & 0.97 & 1.22 & 1.18 & 1.34 & 1.16 \\
\hline Phenylalanine & 0.51 & 0.44 & 0.42 & 0.32 & 0.42 & 0.43 & 0.50 & 0.42 \\
\hline Lysine & 0.19 & 0.19 & 0.20 & 0.09 & 0.09 & 0.17 & 0.20 & 0.19 \\
\hline
\end{tabular}




\section{Conclusions}

Sorghum is a cereal species of world importance, considering its adaptability to unfavorable environmental conditions, which is materialized by obtaining high yields that have very high nutritional qualities and improves human health.

Although the experiments at Secuieni were carried out in extremely unfavourable climatic conditions, characterized as very dry and hot, the sorghum produced large yields, ranging from $7841 \mathrm{~kg} / \mathrm{ha}$ to $9718 \mathrm{~kg} / \mathrm{ha}$. Two of the eight experimented hybrids, respectively Foehn and Shamal, were noted for producing more than $9500 \mathrm{~kg} / \mathrm{ha}$.

The physical indices of the seed were influenced by the characteristics of the hybrid, and together with the high content of starch, protein and raw fibre, they represent an advantage for the use of sorghum in the baking industry. The lipid content is twice as high as wheat flour and has beneficial effects on bakery products. All eight analysed hybrids can be labelled as excellent "iron source" and "magnesium source".

The samples analysed contain all the essential amino acids, in concentrations that, some of them, exceed the recommended daily dose: leucine, isoleucine, histidine and valine. In addition to these, sorghum has a satisfactory content of methionine, threonine and phenylalanine.

This work was supported by a grant of the Romanian Ministery of Research and Innovation CCDI UEFISCDI, "Complex system of integral capitalization of agricultural species with energy and food potential", project number PN-III-P1-1.2-PCCDI-2017-0566, Contract no. 9PCCDI/2018, within PNCDI III.

\section{References}

1. W. D. Clayton, S. A. Renvoize, Genera graminum. Grasses of the World, Kew Bull. Add. Series, 13: 389, ref. 87 (1986)

2. J. Wiersema, J. Dahlberg, The nomenclature of Sorghum bicolor (L.) Moench (Gramineae), Taxon, 56 (3): 941 - 946 (2007)

3. L. W. Rooney, R. D. Waniska, Sorghum food and industrial utilization, In Sorghum: Origin, history, technology and production, 2: 689 - 729, Hoboken, NJ: John Wiley \& Sons (2000)

4. FAO, Food and Agriculture Organization of the United Nation (2017)

5. V. Taleon, L. Dykes, W. L. Rooney, L. W. Rooney, Effect of genotype and environment on flavonoid concentration and profile of black sorghum grains, J. of Cereal Sc., 56 (2): 470 - 475 (2012)

6. Y. Xiong, P. Zhang, J. Luo, S. Johnson, Z. Fang, Effect of processing on the phenolic contents, antioxidant activity and volatile compounds of sorghum grain tea, J. of Cereal Sc., 85: 6 - 14 (2019)

7. W. L. Rooney, L. W. Rooney, J. Awika, L. Dykes, Registration of Tx3362 sorghum germplasm, J. of Plant Registrations, 7 (1): 104 - 107 (2013)

8. S. Shen, R. Huang, C. Li, W. Wu, H. Chen, J. Shi, S. Chen, X. Ye, Phenolic compositions and antioxidant activities differ significantly among sorghum grains with different applications, Molecules, 23 (5): 1203, E1203 (2018)

9. F. M. Gonz'alez - Montilla, R. A. Ch'avez - Santoscoy, J. A. Guti'errez - Uribe, S. O. Serna-Saldivar, Isolation and identification of phase II enzyme inductors obtained from black Shawaya sorghum [Sorghum bicolor (L.) Moench] bran. J. of Cereal Sc., 55 (2): 126 - 131 (2012) 
10. A. R. Cabral, C. Waters, H. L. Laird, L. C. Cavitt, R. K. Miller, W. L. Rooney, C. Z. Alvarado, J. M. Awika, C. R. Kerth, Sorghum bran as an antioxidant in pork and poultry products, Meat and Muscle Biology, 2 (2): 83 (2019)

11. G. Wu, Y. Shen, Y. Qi, H. Zhang, L. Wang, H. Qian, X. Qi, Y. Li, S. K. Johnson, Improvement of in vitro and cellular antioxidant properties of Chinese steamed bread through sorghum addition. LWT - Food Sci. and Techn., 91: 77 - 83 (2018)

12. H. Hill, L. S. Lee, R. J. Henry, Variation in sorghum starch synthesis genes associated with differences in starch phenotype. Food Chemistry, 131 (1): 175 - 183 (2012)

13. USDA, National nutrient database for standard reference legacy release: Full report (all nutrients) 20067, sorghum grain (2019)

14. I. S. Udachan, A. K. Sahu, F. M. Hend, Extraction and characterization of sorghum (Sorghum bicolor L. Moench) starch. Int. Food Res. J., 19 (1): 315 - 319 (2012)

15. H. S. D. Martino, P. A. Tomaz, É. A. Moraes, L. L. da Conceição, D. da. S. Oliveira, V. A. V. Queiroz, J. A. Santos Rodrigues, M. Ribeiro Pirozi, H. M. Pinheiro -Sant'Ana, S. M. R. Ribeiro, Chemical characterization and size distribution of sorghum genotypes for human consumption, Revista do Instituto Adolfo Lutz (Impresso), 71(2): $337-344$ (2012)

16. P. S. Belton, I. Delgadillo, N. G. Halford, P. R. Shewry, Kafirin structure and functionality. J. of Cereal Sc., 44 (3): 272 - 286 (2006)

17. G. Galili, R. Amir, Fortifying plants with the essential amino acids lysine and methionine to improve nutritional quality. Plant Biotech. J., 11 (2): 211 - 222 (2013)

18. J. R. N. Taylor, M. N. Emmambux, Developments in our understanding of sorghum polysaccharides and their health benefits, Cereal Chemistry, 87 (4): 263 - 271 (2010)

19. H. Raza, I. Pasha, M. Shoaib, F. Zaaboul, S. Niazi, W. Aboshora, Review on functional and rheological attributes of kafirin for utilization in gluten free baking industry, Am. J. of Food Sc. and Nutrition Res., 4 (5): 150 - 157 (2017)

20. Regulation (EC) no. 1924/2006 of the European Parliament and of the Council of 20 December 2006 on nutrition and health claims made on foods (2006)

21. Council Directive 90/496/EEC of 24 September 1990 on nutrition labelling for foodstuffs (1990)

22. Food and drug administration, https://www.usa.gov/federal-agencies/food-and-drugadministration (2011) 